\title{
DETERMINATION OF QUIFENADINE BY HPLC METHOD IN BLOOD
}

Topicality. Quifenadine hydrochloride (phencarol) - quinuclidinyl-3-diphenyl carbinol hydrochloride - first generation $\mathrm{H}_{1}$-histamine receptor blocker. The drug reduces the content of histamine in tissues due to the activation of the enzyme diamine oxidase, which breaks down up to $30 \%$ of tissue histamine. Quifenadine hydrochloride is superior to diphenhydramine in duration of antihistamine action. Unlike diphenhydramine and diprazine, quifenadine does not inhibit the CNS, is characterized by weak sedative properties. Quifenadine hydrochloride can be used in the development of tolerance to other sedative antihistamines. Quifenadine hydrochloride is used to treat anaphylactic shock, urticaria, hay fever, Quincke's edema, dermatoses, allergic rhinitis, food and drug allergies. In case of overdose of quifenadine hydrochloride causes dryness of the mucous membranes, headache, vomiting, stomach pain and dyspepsia. At high doses, it can affect the cardiovascular system, gastrointestinal tract, liver and kidneys. Detection and quantification of quifenadine hydrochloride in pharmaceuticals and biological matrices during treatment are based on the choice of highly sensitive and selective research methods, which is an urgent task for monitoring the effectiveness of treatment of the population with antihistamines and diagnosis of drug intoxication.

Aim. To develop an algorithm for directed analysis of quifenadine in biological extracts from blood using a unified method of HPLC research.

Materials and methods. The extraction of quifenadine was carried out with chloroform at $\mathrm{pH} 9.0$. The extracts were purified from impurities by a combination of TLC and extraction with hexane. TLC purification and identification of quifenadine were carried out under optimal conditions: system of organic solvents - chloroform-n-butanol-25\% solution of ammonium hydroxide (70:40:5) and chromatographic plates - Sorbfil PTLC-AF-A. For the detection of quifenadine, the most sensitive location reagents were used - UV light $(\lambda=254 \mathrm{~nm})$ and reagent Dragendorff in the modification of Mounier. Chromatographic analysis has been carried out on a microcolumn liquid chromatograph "Milichrome A-02" (EkoNova, Closed Joint-Stock Company, Novosibirsk, Russia) using standardized HPLC conditions: reversed-phase variant with the use of metal column with non-polar absorbent Prontosil 120-5C 18 AQ $5 \mu \mathrm{m}$; mobile phase in the mode of linear gradient - from eluent A ( $5 \%$ acetonitrile and $95 \%$ buffer solution - $0.2 \mathrm{M}$ solution of lithium perchlorate in $0.005 \mathrm{M}$ solution acid perchloric) to eluent B (100\% acetonitrile) as during $40 \mathrm{~min}$. Regeneration of column has been conducted during $2 \mathrm{~min}$ with mixture of solvents; the flow rate of the mobile phase has been formed $100 \mu \mathrm{l} / \mathrm{min}$, injection volume $-4 \mu \mathrm{l}$. Multichannel detection of the substance was carried out using a two-beam multi-wave UV spectrophotometer at 8 wavelengths of $210,220,230,240,250,260,280$, and $300 \mathrm{~nm}$; the optimal value of column temperature $-37-40^{\circ} \mathrm{C}$ and pressure of pump - 2.8-3.2 MPa.

Results and discussion. Isolation of quifenadine from blood has been carried out according to the developed method, including extraction with chloroform at $\mathrm{pH}$ 9.0; extraction purification of extracts with hexane from impurities; TLC purification and identification of quifenadine. By using a unified HPLC method, quifenadine was identified by retention parameters and spectral ratios. For quantitative determination, a calibration graph or a straight line equation corresponding to this graph were used. The obtained results indicated the reliability and reproducibility of the method. It was found that the relative uncertainty of the average result in the analysis of quifenadine in blood was $\bar{\varepsilon}= \pm 6.65 \%$, the relative standard deviation of the average result was $R S D \bar{x}=2.25 \%$.

Conclusions. Quifenadine was extracted with chloroform at pH 9,0 from blood. Purification of extracts from coextractive compounds was performed by combining TLC and extraction with hexane. It was established that when isolating quifenadine from blood according to the developed methods it is possible to allocate $32.5-37.6 \%$ of substance $(\bar{\varepsilon}= \pm 6.65 \%, R S D \bar{x}=2.25 \%$ ). The method of TLC purification and identification of quifenadine in biogenic extracts was tested under optimal conditions: system of organic solvents - chloroform-n-butanol-25 \% solution of ammonium hydroxide (70:40:5), location reagents - UV light, reagent Dragendorff in the modification of Mounier, $R_{\text {fquifenadine }}=0.25-0.30$ (Sorbfil PTLC-AF-A). The unified HPLC method for identification and quantification of quifenadine has been tested in biogenic extracts from blood according to the developed algorithm of directed analysis. It was found that quifenadine can be identified by retention time $-20.27 \pm 0.03 \mathrm{~min}$; retention volume $2026.9 \pm 0.34 \mu \mathrm{l}$; spectral ratios $-0.634 ; 0.255$; $0.041 ; 0.022 ; 0.027 ; 0.001 ; 0.001$. Equation was used to determine the quifenadine content $\mathrm{S}=0.42 \cdot 10^{-3} \mathrm{C}+0.94 \cdot 10^{-3}$ the correlation coefficient was equal to 0.9985 .Chromatographic techniques can be recommended for implementation in practice of the Bureau of Forensic Medical Examination, poison control centers, clinical laboratories regarding the study of medicinal substances in biological objects.

Key words: quifenadine hydrochloride (phencarol); extraction with chloroform; purification of extracts from impurities by TLC and extraction methods; identification and quantitative determination by HPLC; blood 


\section{О. О. Маміна, В. І. Кабачний, О. В. Лозова*}

Національний фармацевтичний університет Міністерства охорони здоров'я України

* Приватний вищий навчальний заклад «Київський медичний університет»

\section{Визначення хіфенадину ВEPX-методом у крові}

Актуальність. Хіфенадину гідрохлорид (фенкарол) - хінуклідил-3-дифенілкарбінолу гідрохлорид - блокатор рецепторів $\mathrm{H}_{1}$-гістаміну першого покоління. Препарат знижує вміст гістаміну в тканинах, що обумовлено активацією ензиму діаміноксидази, який розщеплює до 30 \% тканинного гістаміну. Хіфенадину гідрохлорид перевершує дифенгідрамін за тривалістю протигістамінної дії. На відміну від дифенгідраміну та дипразину хіфенадин не пригнічує ЦНС і характеризується слабко вираженими седативними властивостями. Хіфенадину гідрохлорид може використовуватися при розвитку толерантності до інших седативних антигістамінних препаратів. Хіфенадину гідрохлорид застосовується для лікування анафілактичного шоку, кропивниці, сінної лихоманки, набряку Квінке, дерматозів, алергічних ринітів, харчової і лікарської алергії. При передозуванні хіфенадину гідрохлорид викликає сухість слизових оболонок, головний біль, блювоту, біль у шлунку і диспепсичні явища. При значних дозах може вражати серцево-судинну систему, шлунково-кишковий тракт, печінку та нирки. Виявлення та кількісне визначення хіфенадину гідрохлориду в фармацевтичних препаратах і біологічних матрицях під час лікування грунтуються на виборі високочутливих і селективних методів дослідження, що $\epsilon$ актуальною задачею для проведення моніторингу ефективності лікування населення антигістамінними лікарськими засобами та діагностики інтоксикацій ліками.

Метою дослідження $є$ розробка алгоритму спрямованого аналізу хіфенадину у біологічних екстрактах із крові при застосуванні уніфікованої методики дослідження ВЕРХ- методом.

Матеріали та методи. Екстракцію хіфенадину проводили хлороформом при рН 9,0. Очистку екстрактів від домішок виконували при сполученні ТШХ і екстракції гексаном. ТШХ-очистку та ідентифікацію хіфенадину проводили в оптимальних умовах: системи органічних розчинників - хлороформ-н-бутанол- 25 \% розчин амонію гідроксиду (70:40:5), $R_{\text {fхіфенадин }}=0,25-0,30$ і хроматографічні пластинки - Сорбфіл ПСТХ-АФ-А. Для детектування хіфенадину використовували найбільш чутливі проявники - УФ-світло ( $\lambda=254$ нм) і реактив Драгендорфа у модифікації за Муньє. Хроматографічний аналіз проводився на мікроколоночному рідинному хроматографі «Міліхром A-02» (EkoNova, ЗАТ, Новосибірськ, Росія) з використанням стандартизованих умов BЕРХ: оберненофазовий варіант із застосуванням металевої колонки з неполярним сорбентом Prontosil 120-5C 18 AQ, 5 мкм; рухлива фаза у режимі лінійного градієнту - від елюєнту А (5 \% ацетонітрил і $95 \%$ буферний розчин - 0,2 M розчин літію перхлорату в 0,005 М розчині кислоти хлорної) до елюєнту В (100\% ацетонітрилу) впродовж 40 хв. Регенерацію колонки проводили впродовж 2 хв сумішшю розчинників; швидкість потоку рухомої фази складала 100 мкл/хв, об’єм проби - 4 мкл. Багатоканальне детектування речовини проводили з використанням двопроменевого мультихвильового УФ-спектрофотометра за 8 значеннями довжини хвилі 210, 220, 230, 240, 250, 260, 280 і 300 нм; оптимальне значення температури колонки $-37-40{ }^{\circ} \mathrm{C}$ та тиску насосу - 2,8-3,2 МПа.

Результати та їх обговорення. Проведено ізолювання хіфенадину з крові за розробленою методикою, що включає екстракцію хлороформом при $\mathrm{pH}$ 9,0; екстракційну очистку витяжок гексаном від домішок; ТШХочистку та ідентифікацію хіфенадину. При використанні уніфікованої ВЕРХ-методики проведено ідентифікацію хіфенадину за параметрами утримування і спектральним відношеннями. Для кількісного визначення використовували градуювальний графік або рівняння прямої, що відповідає цьому графіку. Отримані результати вказували на надійність і відтворюваність методики. Встановлено, що відносна невизначеність середнього результату при аналізі хіфенадину у крові складала $\bar{\varepsilon}= \pm 6,65 \%$, відносне стандартне відхилення середнього результату дорівнювало $R S D \bar{x}=2,25 \%$.

Висновки. Проведено екстракцію хіфенадину хлороформом при рН 9,0 з крові та сечі. Очистку витяжок від співекстрактивних сполук виконували при сполученні методів ТШХ та екстракції гексаном. Встановлено, що при ізолюванні хіфенадину з крові за розробленими методиками можна виділити $32,5-37,6$ \% речовини $(\bar{\varepsilon}= \pm 6,65 \%, R S D \bar{x}=2,25 \%)$. Опрацьовано методику ТШХ-очистки та ідентифікації хіфенадину у біогенних екстрактах за оптимальними умовами: система органічних розчинників - хлороформ-н-бутанол- 25 \% розчин амо-

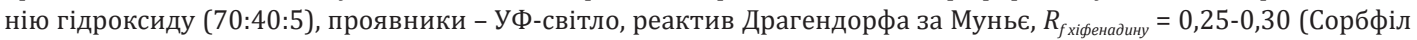
ПСТХ-АФ-А). Опрацьовано уніфіковану ВЕРХ-методику ідентифікації та кількісного визначення хіфенадину у біогенних екстрактах із крові згідно з розробленим алгоритмом спрямованого аналізу. Встановлено, що хіфенадин можна ідентифікувати за часом утримування - 20,27 $\pm 0,03$ хв; об’ємом утримування 2026,9 $\pm 0,34$ мкл; спектральними відношеннями - 0,634; 0,$255 ; 0,041 ; 0,022 ; 0,027 ; 0,001 ; 0,001$. Для визначення вмісту хіфенадину використовували рівняння $\mathrm{S}=0,42 \cdot 10^{-3} \mathrm{C}+0,94 \cdot 10^{-3}$; коефіцієнт кореляції дорівнював 0,9985 . Хроматографічні методики можуть бути рекомендовані для впровадження у практику бюро судово-медичної експертизи, токсикологічних центрів, клінічних лабораторій стосовно вивчення лікарських речовин у біологічних об'єктах.

Ключові слова: хіфенадину гідрохлорид (фенкарол); екстракція хлороформом; очистка екстрактів від домішок ТШХ і екстракційним методами; ідентифікація та кількісне визначення ВЕРХ методом; кров

\section{Е. А. Мамина, В. И. Кабачный, Е. В. Лозовая*}

Национальный фармацевтический университет Министерства здравоохранения Украины

* Частное высшее учебное заведение «Киевский медицинский университет»

\section{Определение хифенадина ВЭЖХ-методом в крови}

Актуальность. Хифенадина гидрохлорид (фенкарол) - хинуклидил-3-дифенилкарбинола гидрохлорид - блокатор рецепторов $\mathrm{H}_{1}$-гистамина первого поколения. Препарат снижает содержание гистамина в тканях, что обусловлено активацией фермента диаминоксидазы, который расщепляет до 30 \% тканевого гистамина. Хифенадина гидрохлорид превосходит дифенгидрамин по продолжительности антигистаминного действия. В отличие от дифенгидрамина и дипразина хифенадин не угнетает ЦНС, характеризуется слабо выраженными седативными свойствами. Хифенадина гидрохлорид может использоваться при развитии толерантности к другим седативным 
антигистаминным препаратам. Хифенадина гидрохлорид применяется для лечения анафилактического шока, крапивницы, сенной лихорадки, отека Квинке, дерматозов, аллергических ринитов, пищевой и лекарственной аллергии. При передозировке хифенадина гидрохлорид вызывает сухость слизистых оболочек, головную боль, рвоту, боли в желудке и диспепсические явления. При значительных дозах может поражать сердечно-сосудистую систему, желудочно-кишечный тракт, печень и почки. Выявление и количественное определение хифенадина гидрохлорида в фармацевтических препаратах и биологических матрицах при лечении основываются на выборе высокочувствительных и селективных методов исследования и являются актуальной задачей для проведения мониторинга эффективности лечения населения антигистаминными лекарственными средствами и диагностики интоксикаций лекарствами.

Целью исследования является разработка алгоритма направленного анализа хифенадина в биологических экстрактах из крови при применении унифицированной методики исследования ВЕЖХ методом.

Материалы и методы. Экстракцию хифенадина проводили хлороформом при рН 9,0. Очистку экстрактов от примесей выполняли при сочетании ТCX и экстракции гексаном. TCX-очистку и идентификацию хифенадина проводили в оптимальных условиях: система органических растворителей - хлороформ-н-бутанол-25 \% раствор аммония гидроксида (70:40:5) и хроматографические пластинки - Сорбфил ПСТХ-АФ-А. Для детектирования хифенадина использовали наиболее чувствительные проявители - УФ-свет $(\lambda=254$ нм) и реактив Драгендорфа в модификации по Мунье. Хроматографический анализ проводился на микроколоночном жидкостном хроматографе «Милихром A-02» (ЭkoNova, 3AO, Новосибирск, Россия) с использованием стандартизированных условий ВЭЖХ: обращенно-фазный вариант с применением металлической колонки с неполярным сорбентом Prontosil 120-5C 18 AQ, 5 мкм; подвижная фаза в режиме линейного градиента - от элюента А (5 \% ацетонитрил и $95 \%$ буферный раствор - 0,2 М раствор лития перхлората в 0,005 М растворе кислоты хлорной) до элюента В (100\% ацетонитрила) в течение 40 мин. Регенерацию колонки проводили в течение 2 мин смесью растворителей; скорость потока подвижной фазы составляла 100 мкл/мин, объем пробы - 4 мкл. Многоканальное детектирование вещества проводили с использованием двухлучевого мультиволнового УФ-спектрофотометра по 8 значениям длины волны 210, 220, 230, 240, 250, 260, 280 и 300 нм; оптимальное значение температуры колонки $-37-40^{\circ} \mathrm{C}$ и давления насоса - 2,8-3,2 МПа.

Результаты и их обсуждение. Проведено изолирование хифенадина из крови по разработанной методике, включающей экстракцию хлороформом при рН 9,0; экстракционную очистку вытяжек гексаном от примесей; ТСХ-очистку и идентификацию хифенадина. При использовании унифицированной ВЭЖХ-методики проведена идентификация хифенадина по параметрам удерживания и спектральным отношениям. Для количественного определения использовали калибровочный график или уравнение прямой, соответствующей этому графику. Полученные результаты указывали на надежность и воспроизводимость методики. Установлено, что относительная неопределенность среднего результата при анализе хифенадина в крови составляла $\bar{\varepsilon}= \pm 6,65 \%$, относительное стандартное отклонение среднего результата было равным $R S D \bar{x}=2,25 \%$.

Выводы. Проведена экстракция хифенадина хлороформом при рН 9,0 из крови. Очистку вытяжек от соэкстрактивных веществ выполняли при сочетании методов ТСХ и экстракции гексаном. Установлено, что при изолировании хифенадина из крови по разработанным методикам можно выделить 32,5-37,6 \% вещества $(\bar{\varepsilon}= \pm 6,65 \%, R S D \bar{x}=2,25 \%)$. Апробирована методика ТСХ-очистки и идентификации хифенадина в биогенных экстрактах при оптимальных условиях: система органических растворителей - хлороформ-н-бутанол- 25 \% раствор

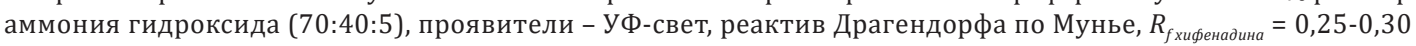
(Сорбфил ПСТХ-АФ-А). Апробирована унифицированная ВЭЖХ-методика идентификации и количественного определения хифенадина в биогенных экстрактах из крови согласно разработанному алгоритму направленного анализа. Установлено, что хифенадин можно идентифицировать по времени удерживания - 20,27 $\pm 0,03$ мин;

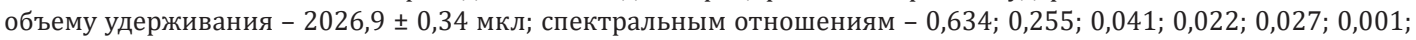
0,001 . Для определения содержания дифенгидрамина использовали уравнение $\mathrm{S}=0,42 \cdot 10^{-3} \mathrm{C}+0,94 \cdot 10^{-3} ;$ коэффициент корреляции составлял 0,9985. Хроматографические методики могут быть рекомендованы для внедрения в практику бюро судебно-медицинской экспертизы, токсикологических центров, клинических лабораторий по изучению лекарственных веществ в биологических объектах.

Ключевые слова: хифенадина гидрохлорид (фенкарол); экстракция хлороформом; очистка экстрактов от примесей ТСХ и экстракционным методами; идентификация и количественное определение ВЭЖХ методом; кровь

\section{INTRODUCTION}

Quifenadine hydrochloride (phencarol) - quinuclidinyl-3-diphenyl carbinol hydrochloride - first generation $\mathrm{H}_{1}$-histamine receptor blocker. The drug reduces the content of histamine in tissues due to the activation of the enzyme diamine oxidase, which breaks down up to $30 \%$ of tissue histamine. Quifenadine hydrochloride is superior to diphenhydramine in duration of antihistamine action. Unlike diphenhydramine and diprazine, quifenadine does not inhibit the CNS, is characterized by weak sedative properties. Quifenadine hydrochloride can be used in the development of tolerance to other sedative antihistamines $[1,2]$.
The drug penetrates poorly through the blood-brain barrier, reduces the possibility of spasms of intestinal smooth muscle, reduces the hypotensive effect and the effect on capillary permeability, has a moderate antiserotonin and weak cholinolytic effect. Quifenadine hydrochloride is used to treat anaphylactic shock, urticaria, hay fever, Quincke's edema, dermatoses, allergic rhinitis, food and drug allergies [3].

In case of overdose of quifenadine hydrochloride causes dryness of the mucous membranes, headache, vomiting, stomach pain and dyspepsia. At high doses, it can affect the cardiovascular system, gastrointestinal tract, liver and kidneys. Quifenadine hydrochloride does not 
enhance the inhibitory effect of ethanol and hypnotics on the CNS, but has weak m-anticholinergic properties, reduces gastrointestinal motility and enhances the absorption and cumulative properties of other drugs [4].

Detection and quantification of quifenadine hydrochloride in pharmaceuticals and biological matrices during treatment are based on the choice of highly sensitive and selective research methods, which is an urgent task for monitoring the effectiveness of treatment of the population with antihistamines and diagnosis of drug intoxication.

According to toxicological studies, one of the leading places among drug poisonings is occupied by intoxication with antihistamines, due to the multi-vector pharmacological effects, uncontrolled use of many combined drugs for the treatment of seasonal diseases $[5,6]$.

According to the literature, systematic studies of most antihistamines of the first generation are absent, insufficiently studied methods of their isolation, identification, quantification in biological objects, which determines the relevance of such studies using modern highly sensitive and selective methods of analysis $[6,7]$.

The development of the analytical service in the directions of monitoring the effectiveness of treatment of the population with antihistamines and diagnosis of intoxications with the use of these drugs is based on the creation of databases of effective, economical and express methods of drug analysis in biological objects using a unified HPLC study method [7, 8].

The aim is to develop an algorithm for directed analysis of quifenadine in biological extracts from blood using a unified method of HPLC research.

\section{MATERIALS AND METHODS}

Quifenadine is determined in drugs and biological objects by highly sensitive methods: spectrophotometric [9], extraction-photometric [10], spectrofluorimetric [11], electrochemical [12], chromatographic methods thin layer chromatography (TLC) $[8,13]$, high performance liquid chromatography (HPLC) $[8,14,15]$.

The most common highly sensitive and selective chromatographic methods of chemical and toxicological analysis of first-generation antihistamines are HPLC and TLC. These methods, in contrast to the spectral and electrochemical methods, are widely used for the separation of mixtures of drugs, for the detection of impurities and purification from them.

The literature presents HPLC methods for the study of antihistamines using different conditions (options for detecting the test substance, the use of isocratic and gradient modes of elution, the use of different composition of mobile phases, sorbents, buffer solutions).

Kaverina L. P. and co-authors developed a method of HPLC analysis to study the pharmacokinetics of suprastin and phencarol in the blood plasma of rats [14]. HPLC method was based on the use of ion-pair and reversedphase chromatography (chromatograph model - Allech,
USA, 320) with a UV-detector (Allech, USA, 153). Detection of substances was carried out at a wavelength of $254 \mathrm{~nm}$; Columns (250 mm $\times 4.6 \mathrm{~mm}$ ) and Pre-Columns (40 mm $\times 3.2 \mathrm{~mm}$ ) Partisil - 10 ODS, $10 \mu \mathrm{m}$. Mobile phase: methanol - water - acid propionic (90:10:0.2), the system is saturated with ammonium dihydrophosphate at $20^{\circ} \mathrm{C}$. The flow rate of the eluent in the column $-1.5 \mathrm{ml} / \mathrm{min}$. Time of chromatographic analysis - 15-20 min.

For HPLC separation of antihistamines, the use of different conditions is recommended:

- column with a Chromolith Fast Gradient RP-18 phase ( $50 \mathrm{~mm} \times 2 \mathrm{~mm}, 5 \mu \mathrm{m}$ ). The mobile phase consisted of two eluents: A $-0.1 \%$ aqueous solution of acid trifluoroacetic and B - $0.1 \%$ solution of acid trifluoroacetic in acetonitrile. The linear gradient of the mobile phase was from $5 \%$ to $95 \%$ of phase B. The flow rate of the eluent in the column $-1.0 \mathrm{ml} / \mathrm{min}$; volume of the injected sample - $200 \mathrm{nl}$. Detection of the investigated compounds was carried out at $230 \mathrm{~nm}$ [15]; - column Spherisorb S5W (125 mm × $4.9 \mathrm{~mm}, 5 \mu \mathrm{m})$; mobile phase $-0.01 \mathrm{M}$ methanol solution of ammonium perchlorate with the addition of $0.1 \mathrm{M}$ methanol solution of sodium hydroxide to $\mathrm{pH}$ 6.7. The flow rate of the eluent in the column $-1.0 \mathrm{ml} / \mathrm{min}$; volume of the injected sample $-1.0 \mu$ l. Detection of the substances was carried out at $230 \mathrm{~nm}$ [8].

The disadvantages of the above HPLC techniques are the use of isocratic elution regime $[8,14]$, which limits the ability to exit the column of all components of the sample in the form of narrow zones and effectively separate mixtures of drugs. Detection at one wavelength $[8,14,15]$ reduces the reliability of the results obtained in the identification and study of mixtures with other drugs, because it allows to use only the retention parameters without the use of spectral ratios.

Modern HPLC methods for the analysis of quifenadine indicate the absence of systematic studies, which does not allow the selection of optimal conditions for the analysis of the drug in biological objects and pharmaceuticals.

To achieve these aims, need to solve the following tasks:

1. To carry out extraction of quifenadine according to the developed technique isolation of organic substances of the basic character from biological objects.

2 . To select the optimal conditions for TLC purification and identification of quifenadine in biogenic extracts (thin layers of sorbents, organic solvent systems, substance detection agent).

3. To approve a unified HPLC method for identification and quantification of quifenadine in biogenic extracts from blood according to the developed algorithm of directed analysis in biological extracts using a unified HPLC method.

Quifenadine hydrochloride (phencarol) was isolated from tablets "Phencarol" (10 pcs) with 25 mg (OLFA, Olainfarm, Joint-Stock Company, Latvia) as follows: the number of tablets, which contained $300 \mathrm{mg}$, were transferred 
to the porcelain mortar and were triturated to a homogeneous state. $100.0 \mathrm{ml}$ of methanol was added to the mixture and mixed thoroughly. The resulting mixture was filtered through a paper filter in porcelain cup and evaporated in water bath at a temperature not higher than $40{ }^{\circ} \mathrm{C}$ to remove the organic solvent; the residue was dried.

It was added $0.1000 \mathrm{~g}$ of test substance to a $100.0 \mathrm{ml}$ volumetric flask, dissolved in methanol and the volume of the solution was adjusted to the mark with solvent (standard solution, concentration $1000.0 \mu \mathrm{g} / \mathrm{ml}$ ).

Organic solvents corresponded to the qualification of "PFA": chloroform, methanol, hexane (Sigma-Aldrich, USA). Reagents corresponded to the qualification of "PFA": $10 \%$ solution of acid trichloroacetic, $25 \%$ solution of ammonium hydroxide, $0.1 \mathrm{M}$ solution of sodium hydroxide (Chimmed, Moscow, Russia).

According to the algorithm for the study of biological objects for the presence of drugs, the following steps were performed: isolation of the substance from the biological object, purification from nutrients, identification and quantification. Purification of extracts from co-extractive compounds was performed by combining TLC and hexane extraction.

A model mixture of blood with quifenadine hydrochloride was used for the investigation. To $10 \mathrm{ml}$ of the appropriate biological fluid was added $1000.0 \mu$ g of quifenadine hydrochloride using an methanol solution of the drug substance, which contained $1000.0 \mu \mathrm{g} / \mathrm{ml}$, as well as control samples. Samples were left for $24 \mathrm{~h}$ at room temperature. A day later, studies were performed according to the developed extraction techniques.

Methods of isolation of quifenadine from blood and extraction purification by hexane. To $10.0 \mathrm{ml}$ of a model mixture of blood with quifenadine hydrochloride, $5.0 \mathrm{ml}$ of $10 \%$ solution of acid trichloroacetic was added for breaking bonds with proteins, mixed and checked with a universal indicator $\mathrm{pH}$ of the mixture - 2.0-2.5, left for $2 \mathrm{~h}$ with constant stirring at room temperature.

The mixture was centrifuged at 3000-5000 rpm for $10 \mathrm{~min}$, the the liquid over the precipitate was separated. Lipid impurities were extracted three times with hexane in portions of $5 \mathrm{ml}$. Hexane phases were not investigated.

The aqueous layer was alkalinized with a $0.1 \mathrm{M}$ solution of sodium hydroxide to $\mathrm{pH} 9.0$ and the quifenadinebase was extracted twice with chloroform in portions of $10.0 \mathrm{ml}$ followed by centrifugation at 3000-5000 rpm for $10 \mathrm{~min}$ for the destruction of water-chloroform emulsions. Chloroform extracts were combined and filtered through a paper filter ("red tape") with 1.0 g sodium sulphate anhydrous, TLC-purification of the extracts was performed.

Methods of TLC purification of biogenic extracts. The purified chloroform solutions were evaporated at room temperature to dryness, which was dissolved in 2.0-3.0 ml of methanol, then quantitatively transferred to a volumetric flask with a capacity of $5.0 \mathrm{ml}$, brought to the mark with methanol.
TLC purification was performed under conditions chromatographic plates Sorbfil PTLC-AF-A, system of organic solvents - chloroform-n-butanol-25\% solution of ammonium hydroxide (70:40:5), $R_{\text {fquifenadine }}=0.25-0.30$, impurities are located at the start line or at the finish line. Detection of quifenadine was performed under uniform conditions using the most sensitive developers - UV light $(\lambda=254 \mathrm{~nm})$ - purple color of the spots, sensitivity 0.3-0.5 $\mu \mathrm{g}$ in the sample, reagent Dragendorff in the modification of Mounier - orange color of the spots, sensitivity of the developer - 1.0-3.0 $\mu \mathrm{g}$ of the substance in the sample [16].

TLC purification of quifenadine in the extracts was performed according to the following method: $1.0 \mathrm{ml}$ of methanol solution of quifenadine after extraction purification, evaporated to $0.3-0.5 \mathrm{ml}$. At the starting line of the chromatographic plate at a distance of $1-2 \mathrm{~cm}$ from the edge to the point was applied using a calibrated capillary witness $-0.01 \%$ methanol solution of quifenadine. At a distance of 1-2 cm from the witness was applied an extract from the control sample, the diameter of the stain should not exceed $0.5 \mathrm{~cm}$. Methanol solution of quifenadine after extraction purification was applied in the form of a strip 1.0-1.5 cm long.

The chromatographic plate was placed in a chromatography chamber, which was a glass vessel with a ground lid with a volume of $500 \mathrm{~cm}^{3}$, into which a system of solvents for chromatography ( $50 \mathrm{ml}$ ) was introduced, the chamber was carefully closed, followed by solvent vapor saturation for at least 30-60 minutes. The length of the mobile phase front was $7 \mathrm{~cm}$. Chromatography was completed when the solvent reached the finish line. The chromatographic plate was dried at room temperature, after which its part with spots of the witness and extracts from control sample was developed using UV light and Dragendorf reagent in the Mounier modification.

At the level of the spot of standard methanol $0.01 \%$ solution of quifenadine from the part of the plate that was not treated with the developer, removed a layer of sorbent with an area of $4-5 \mathrm{~cm}^{2}$, transferred to the filter. The substance was eluted three times with methanol of $5.0 \mathrm{ml}$ and the resulting solution was filtered through a filter ("red tape").

The resulting solutions were evaporated at room temperature to dryness, which was dissolved in $2.0-3.0 \mathrm{ml}$ of methanol, and then quantitatively transferred to a volumetric flask with a capacity of $5.0 \mathrm{ml}$, brought to the mark with methanol.

Methods of research of quifenadine by HPLC method. Chromatographic analysis was carried out on a microcolumn liquid chromatograph "Milichrome A-02" (EkoNova, Closed Joint-Stock Company, Novosibirsk, Russia) according to the unified HPLC method developed by Baram G. Y. [17]: reversed-phase variant with using of metal column with non-polar absorbent Prontosil 120-5C 18 AQ 5 \%m; mobile phase in the mode of linear gradient - from eluent A (5\% acetonitrile and $95 \%$ buffer solution $-0.2 \mathrm{M}$ 
THE RESULTS OF HPLC ANALYSIS OF QUIFENADINE IN BLOOD EXTRACTS ( $\mathrm{n}=5, \mathrm{P}=95 \%$ )

\begin{tabular}{|c|c|c|c|c|c|c|c|c|}
\hline \multirow{2}{*}{$\begin{array}{l}\text { The value of the } \\
\text { area of the peaks } \\
\mathrm{S}, \mathrm{mm}^{2}\end{array}$} & \multicolumn{2}{|c|}{ Quifenadine was isolated } & \multicolumn{6}{|c|}{ Metrological characteristics, $\%$} \\
\hline & $\mu \mathrm{g}$ & $\%$ & $\bar{X}$ & $S$ & $R S D \bar{x}$ & $\overline{S x}$ & $\Delta \bar{x}$ & $\bar{\varepsilon}$ \\
\hline 0.0064 & 13.00 & 32.5 & & & & & & \\
\hline 0.0068 & 13.92 & 34.8 & & & & & & \\
\hline 0.0069 & 14.04 & 35.1 & 35.24 & 1.78 & 2.25 & 0.84 & 2.34 & 6.65 \\
\hline 0.0070 & 14.48 & 36.2 & & & & & & \\
\hline 0.0073 & 15.04 & 37.6 & & & & & & \\
\hline
\end{tabular}

solution of lithium perchlorate in $0.005 \mathrm{M}$ solution acid perchloric) to eluent B (100\% acetonitrile) as during 40 min. Regeneration of column has been conducted during 2 min with mixture of solvents; the flow rate of the mobile phase has been formed $100 \mu \mathrm{l} / \mathrm{min}$, injection volume $-4 \mu \mathrm{l}$.

Multichannel detection of the substance was carried out using a two-beam multi-wave UV spectrophotometer at 8 wavelengths of $210,220,230,240,250,260,280$, and $300 \mathrm{~nm}$; the optimal value of column temperature $37-40{ }^{\circ} \mathrm{C}$ and pressure of pump - 2.8-3.2 $\mathrm{MPa}$.

\section{RESULTS AND DISCUSSION}

Identification of quifenadine has been performed by retention parameters and spectral ratios. It was found that the absolute retention time of quifenadine was $20.27 \pm 0.03 \mathrm{~min}$, the absolute retention volume was $2026.9 \pm 0.34 \mu$ l. To obtain reliable identification results, the spectral ratios of the optical density values at wavelengths from 220 to $280 \mathrm{~nm}$ to the optical density values at $210 \mathrm{~nm}$ were determined $-0.634 \pm 0.005 ; 0.255 \pm 0.006$; $0.041 \pm 0.005 ; 0.022 \pm 0.004 ; 0.027 \pm 0,004 ; 0.001 \pm 0.006$; $0.001 \pm 0.008$.

Peak symmetry coefficients and capacitance coefficients were determined to verify the choice of chromatography conditions. It was found that the values of the coefficients of symmetry of the peaks were equal to $1.01 \pm 0.05$ (less than 2.0-2.5) and the coefficients of capacity $12.51 \pm 0.02$ (more than 0.5-2.0) showed the suitability of the chromatographic system HPLC analysis.

The method of determination of quifenadine by HPLC was validated by the parameters: range of linearity, limits of quantitative determination (LOQ), accuracy and precision in the areas of low, medium and high concentrations of the test substance [18]. To quantify quifenadine, the absolute calibration method was used using the area of the peaks of the substances.

The concentration of quifenadine in methanol solution $(\mathrm{C}, \mu \mathrm{g} / \mathrm{ml})$, which was obtained after purification of biogenic extracts by TLC and extraction methods, was calculated using a calibration graph or the equation of the line corresponding to the calibration graph.

The linearity of the calibration graph was observed in the concentration ranges of 5.0-100.0 $\mu \mathrm{g} / \mathrm{ml}$, which corresponded to the content of quifenadine in the sample ( $4 \mu \mathrm{l})$ from $20.0 \mathrm{ng}$ to $400.0 \mathrm{ng}$. The lower limit of determination of quifenadine by HPLC was $5.0 \mu \mathrm{g} / \mathrm{ml}$ (20.0 ng in the sample).
The equation of the linear dependence of the area of quifenadine peaks $\left(\mathrm{S}, \mathrm{mm}^{2}\right)$ on its concentration $(\mathrm{C}, \mu \mathrm{g} / \mathrm{ml})$ had the form: $\mathrm{S}=0.42 \cdot 10^{-3} \mathrm{C}+0.94 \cdot 10^{-3}$. The correlation coefficient was 0.9985 [18].

When performing HPLC analysis of quifenadine in model solutions using the proposed method, the relative uncertainty of the average results did not exceed $\pm 1.87 \%$, which indicated the suitability of HPLC conditions for analysis in biological objects [18].

The amount of quifenadine in samples of blood was calculated by the formula:

$$
\mathrm{C}_{\mathrm{x}}=\frac{\mathrm{C} \cdot \mathrm{V}_{1} \cdot \mathrm{V}_{3} \cdot \mathrm{k} \cdot 100}{\mathrm{a} \cdot \mathrm{V}_{2}},
$$

where: $\mathrm{C}_{\mathrm{x}, \%}$ - mass fraction of quifenadine in $10 \mathrm{ml}$ of blood, in \%; $V_{1}$ - volume of a volumetric flask with methanol extract of the substance from blood after extraction purification ( $5 \mathrm{ml}$ ); $\mathrm{V}_{2}$ - volume of methanol extract of the substance from blood, taken for TLC purification $(1 \mathrm{ml}) ; \mathrm{V}_{3}$ - volume of the volumetric flask with the extract after TLC purification using methanol ( $5 \mathrm{ml}$ ); $\mathrm{k}$ - coefficient of recount, which is equal to the ratio of molecular weights of salt/base; a - weight of the sample of quifenadine hydrochloride, which is made in $10.0 \mathrm{ml}$ of blood (1000.0 $\mu \mathrm{g})$.

The results of the study are shown in Tab 1.

According to the results of research it is established that when isolating quifenadine from blood according to the developed methods it is possible to allocate $32.5-37.6 \%$ of substance $(\bar{\varepsilon}= \pm 6.65 \%, R S D \bar{x}=2.25 \%)$.

According to the results of HPLC and TLC studies, an algorithm for directed blood analysis for quifenadine was developed (Tab. 2).

When comparing the developed algorithm for the analysis of quifenadine in the blood with the previously mentioned study [10], it was found that to break the bonds of quifenadine with proteins used a $20 \%$ solution of sulfuric acid to $\mathrm{pH}$ 2.0; for extraction of quifenadine-base used chloroform at pH 8.0 after adding $25 \%$ ammonia solution.

Extraction-photometric method with bromothymol blue was used for quantitative determination of quifenadine. As a result of application of this technique 56.89-57.11\% of quifenadine were allocated from blood.

Thus, in the above algorithm of analysis there was no stage of purification of extracts from impurities. According to the literature, the use of strong acids to break 


\section{ALGORITHM FOR DIRECTED ANALYSIS OF QUIFENADINE IN BLOOD}

\begin{tabular}{|c|c|}
\hline Stage of the algorithm & Conditions of performance \\
\hline $\begin{array}{l}\text { Destruction binding of } \\
\text { quifenadine to proteins }\end{array}$ & $\begin{array}{l}\text { To } 10.0 \mathrm{ml} \text { of a model mixture of blood with quifenadine hydrochloride, } 5.0 \mathrm{ml} \text { of } 10 \% \text { solution } \\
\text { of acid trichloroacetic was added mixed and checked with a universal indicator } \mathrm{pH} \text { of the } \\
\text { mixture-2.0-2.5, left for } 2 \mathrm{~h} \text { with constant stirring at room temperature }\end{array}$ \\
\hline $\begin{array}{l}\text { Extraction purification by } \\
\text { hexane }\end{array}$ & $\begin{array}{l}\text { The mixture was centrifuged at } 3000-5000 \mathrm{rpm} \text { for } 10 \mathrm{~min} \text {, the the liquid over the precipitate } \\
\text { was separated. Lipid impurities were extracted three times with hexane in portions of } 5 \mathrm{ml} \text {. } \\
\text { Hexane phases were not investigated }\end{array}$ \\
\hline $\begin{array}{l}\text { TLC-purification and } \\
\text { preliminary identification } \\
\text { of quifenadine in extracts }\end{array}$ & $\begin{array}{l}\text { System of organic solvents - chloroform-n-butanol-25 \% solution of ammonium hydroxide } \\
\text { (70:40:5), developers - UV light, Dragendorff reagent modified by Munie, } R_{\text {fquifenadine }}=0.25-0.30 \\
\text { (Sorbfil PTLC-AF-A) }\end{array}$ \\
\hline
\end{tabular}

the bonds of the substance with proteins is the cause of significant contamination of blood extracts with organic impurities, and the results may be false positive [19]

The algorithm developed as a result of the presented research had advantages:

- the use of a unified HPLC technique made it possible to identify quifenadine by retention parameters and spectral ratios, which made the results accurate, reliable and reproducible;

- the use of a linear gradient mode of elution of quifenadine allowed to obtain symmetrical, sharp chromatographic peaks (peak symmetry coefficient did not exceed 2-2.5) and to carry out their reliable processing. The results of identification and quantification by HPLC were calculated using a computer program "Multichrome" (CJSC "Ampersend", Moscow, Russia), which was included in the chromatograph;

- $\quad$ high degree of purification of extracts from impurities allowed to obtain reliable and reproducible results in accordance with metrological characteristics.

The disadvantages of the developed analysis algorithm were the low degree of quifenadine extraction from the blood$32.5-37.6 \%$ of the substance. These results were due to losses in the multi-stage purification of extracts from impurities, as well as the use of a unified method of extraction of the substance without taking into account the individual properties of quifenadine.

Chromatographic techniques can be recommended for implementation in practice of the Bureau of Forensic Medical Examination, poison control centers, clinical laboratories regarding the study of medicinal substances in biological objects.

\section{CONCLUSIONS}

1. Quifenadine was extracted with chloroform at $\mathrm{pH} 9.0$ from blood. Purification of extracts from co-extractive compounds was performed by combining TLC and extraction with hexane. It is established that when isolating quifenadine from blood according to the developed methods it is possible to allocate $32.5-37.6 \%$ of substance $(\bar{\varepsilon}= \pm 6.65 \%, R S D \bar{x}=2.25 \%)$.

2. The method of TLC purification and identification of quifenadine in biogenic extracts was tested under optimal conditions: system of organic solvents - chloroform-n-butanol-25 \% solution of ammonium hydroxide (70:40:5), location reagents - UV light, reagent Dragendorff in the modification of Mounier, $R_{\text {fquifenadine }}=0.25-0.30$ (Sorbfil PTLC-AF-A).

3. The unified HPLC method for identification and quantification of quifenadine was tested in biogenic extracts from blood according to the developed algorithm of directed analysis. It was found that quifenadine can be identified by retention time $-20.27 \pm 0.03 \mathrm{~min}$; retention volume $2026.9 \pm 0.34 \mu \mathrm{l}$; spectral ratios $0.634 ; 0.255 ; 0.041 ; 0.022 ; 0.027 ; 0.001 ; 0.001$. Equation was used to determine the quifenadine content $\mathrm{S}=0.42 \cdot 10^{-3} \mathrm{C}+0.94 \cdot 10^{-3}$ the correlation coefficient was equal to 0.9985 .

4. Chromatographic techniques can be recommended for implementation in practice of the Bureau of Forensic Medical Examination, poison control centers, clinical laboratories regarding the study of medicinal substances in biological objects.

Conflict of interests: authors have no conflict of interests to declare. 


\section{REFERENCES}

1. Машковский М. Д. Лекарственные средства. 16-е изд., перераб., испр. и доп. Москва : Новая Волна, 2012. 1216 с.

2. Church M. K. Allergy, Histamine and Antihistamines. Handb. Exp. Pharmacol. 2017. Vol. 241. P.321-331. DOI: https://doi.org/10.1007/164_2016_85 (Date of access: 20.07.2020).

3. Tiligada E., Ennis M. Histamine pharmacology: from Sir Henry Dale to the 21st century. British Journal of Pharmacology. 2020. Vol. 177. P. 469-489. DOI: https://doi.org/10.1111/bph.14524 (Date of access: 20.07.2020).

4. Соболенко Т. М. Применение $\mathrm{H}_{1}$-антигистаминных средств в клинической практике: проблемы и решения. Медицинские новости. 2016 № 3. C. 4-9. URL: https://cyberleninka.ru/article/n/primenenie-n1-antigistaminnyh-sredstv-v-klinicheskoy-praktike-problemy-i-resheniya/ viewer (дата обращения: 20.07.2020).

5. Токсические эффекты блокаторов $\mathrm{H}_{1}$ - гистаминовых рецепторов и механизмы их формирования / С. М. Дроговоз и др. Современные проблемы токсикологии. 2012. № 3-4. С. 58-59.

6. Thomas S. H. L. Antihistamine poisoning. Medicine. 2012. Vol. 40, № 3. P. 109-110. DOI: https://doi.org/10.1016/j.mpmed.2011.12.012 (Date of access: 20.07.2020).

7. Намазова-Баранова Л. С. Смертность от антигистаминных препаратов первого поколения. Позиция регуляторных органов. Позиция врача-педиатра. Педиатрическая фармакология. 2009. № 3. С. 52.

8. Robinson A. E. Isolation and Identification of Drugs in Pharmaceuticals, Body Fluids and Postmortem Material /ed. by E. J. C.Clarke. London : The Pharm. Press, 2011. 2463 p. DOI: https://doi.org/10.1111/j.2042-7158.1969.tb08319.x (Date of access: 20.07.2020).

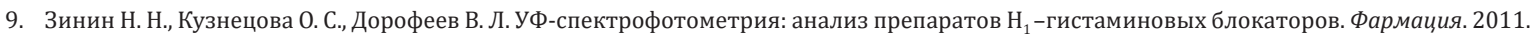
№ 6. С.9-12.

10. Кабденова А. Т. Химико-токсикологическое исследование фенкарола : автореф. дис. ... канд. фармацевт. наук. Алматы, 1995. 23 с.

11. Determination of phencarol in biological fluids / E. V. Okina et al. Scientific research and their practical application modern state and ways of development: conference, 1-12 October, 2013. URL: https://www.sworld.com.ua/konfer32/691.pdf (Date of access: 20.07.2020).

12. Харитонов С. В., Зарембо В. И. Мембранные ионоселективные электроды для количественного определения супрастина и фенкарола. Химия и химическая технология. 2006. Т. 49, № 1. С. 28-31.

13. Тыжигирова В. В., Булка Г. Н. Экспресс-анализ антигистаминных лекарственных средств блокаторов $\mathrm{H}_{1}$-рецепторов. Eстествознание и гуманизм : сб. науч. тр. Иркутск, 2007. Т. 4, № 3. С. 1-3.

14. Каверина Л. П., Дорохов В. В., Холодов Л. Е. Исследование фармакокинетики супрастина и фенкарола у крыс методом высокоэффективной жидкостной хроматографии. Химико-фармацевтический журн. 1983. Т. 17, № 1. С. 29-34.

15. Majors R. E. New Chromatography Columns and Accessories at Pittcon 2008: Part 1. LCGC. 2008. Vol. 26, № 3. P. $238-253$.

16. Mamina O. O., Kabachny V. I. Extraction and determination of phencarol in urine. Advances of science. Perspectives of science and education : proceedings of the IV International scientific-practical conference, September 28, 2018. Czech Republic, Karlovy Vary - Ukraine, Kyiv. P. $1680-1687$.

17. Барам Г. И. Хроматограф «Милихром А-02». Определение веществ с применением баз данных «ВЭЖХ-УФ». Новосибирск : ЗАО Институт хроматографии, 2005. $64 \mathrm{c}$.

18. Teleutsa V., Mamina O. O., Kabachny V. I. Analysis of phencarol by HPLC method. Topical issues of new drugs development : XXIV International Scientific And Practical Conference of Young Scientists and Students, April 20-21, 2017, Kharkiv. Kharkiv, 2017. Vol. 1. P. $205-206$.

19. Prabu S. L., Suriyaprakash T. N. K. Extraction of Drug from the Biological Matrix : a review. Applied Biological Engineering : Principles and Practice. London, 2012. P. 479-506. DOI: https://doi.org/10.5772/32455 (Date of access: 20.07.2020)

\section{REFERENCES}

1. Mashkovskiy, M. D. (2012). Lekarstvennyye sredstva. Moscow: Novaia Volna, 1216

2. Church, M. K. (2017). Allergy, Histamine and Antihistamines. Handbook of Experimental Pharmacology, 241, 321-331. doi: 10.1007/164-2016-85.

3. Tiligada, E., Ennis, M. (2020). Histamine pharmacology: from Sir Henry Dale to the 21st century. British Journal of Pharmacology. 177, 469-489. doi: $10.1111 /$ bph.14524.

4. Sobolenko, T. M. (2016). Meditsinskiye novosti, 3, 4-9.

5. Drogovoz, S. M., Lukianchuk, V. D., Sherman, B. S., Kononenko, A. V. (2012). Sovremennye problemy toksikolohii, 3-4, 58-59.

6. Thomas, S. H. L. (2012). Antihistamine poisoning. Medicine, 40 (3), 109-110. doi: https://doi.org/10.1016/j.mpmed.2011.12.012.

7. Namazova-Baranova, L. S. (2009). Pediatricheskaia farmakolohiia, 3, 52.

8. Clarke, E. J. C. (2011). Isolation and Identification of Drugs in Pharmaceuticals, Body Fluids and Postmortem Materia. London: The Pharm. Press, 2463. doi: https://doi.org/10.1111/j.2042-7158.1969.tb08319.x.

9. Zinin, N. N., Kuznetsova, O. S., Dorofeyev V. L. (2011). Farmatsiia, 6, 9-12.

10. Kabdenova, A. T. (1995). Khimiko-toksikolohicheskoe issledovanie fenkarola. Extended abstract of candidates thesis. Almaty, 23.

11. Okina, E. V., Uskova, E. N., Maksimova, A. A., Soldatova, O. N. (2013). Determination of phencarol in biological fluids. Scientific research and their practical application modern state and ways of development: conference (1-12 October, 2013). Available at: http://www.sworld.com.ua/index.php/ $\mathrm{ru} /$ conference/the-content-of-conferences/archives-of-individual-conferences/oct-2013.

12. Kharitonov, S. V., Zarembo, V. I. (2006). Khimiia i khimicheskaia tekhnolohiia, 49 (1), 28-31.

13. Tyzhihirova, V. V., Bulka, H. N. (2007). Yestestvoznanie i humanizm : sb. nauch. tr. Irkutsk, 4 (3), 1-3.

14. Kaverina, L. P., Dorokhov, V. V., Kholodov L. Ye. (1983). Khimiko-farmatsevticheskii zhurnal, 17 (1), 29-34.

15. Majors, R. E. (2008). New Chromatography Columns and Accessories at Pittcon 2008: Part 1. Liquid Chromatography Gas Chromatography, 26 (3), 238-253.

16. Mamina, O. O., Kabachny, V. I. (2018). Extraction and determination of phencarol in urine. Advances of science - 2018: Perspectives of science and education: Proceedings of the IV International scientific-practical conference (September 28, 2018). (pp. 1680-1687). Czech Republic, Karlovy Vary Ukraine, Kyiv.

17. Baram, H. I. (2005). Khromatohraf «Milikhrom A-02». Opredelenie veshchestv s primeneniem baz dannykh «VEZHKH-UF». Novosibirsk: ZAO Institut khromatografii, 64.

18. Teleutsa, V., Mamina, O. O., Kabachny, V. I. (2017). Analysis of phencarol by HPLC method. Topical issues of new drugs development: XXIV International Scientific And Practical Conference of Young Scientists and Students (April 20-21, 2017). (Vols. 1-2; Vol. 1). (pp. 205-206). Kharkiv.

19. Prabu, S. L., Suriyaprakash, T. N. K. (2012). Extraction of Drug from the Biological Matrix : a review. Applied Biological Engineering : Principles and Practice. London, 479-506. doi: 10.5772/32455. 
Information about authors:

Mamina O., Doctor of Pharmaceutical Sciences, Professor of the Department of Inorganic and Physical Chemistry, National University of Pharmacy of the Ministry of Health of Ukraine. E-mail: a_mamina@ukr.net. ORCID: http://orcid.org/0000-0001-6673-1488 Kabachny V., Doctor of Pharmaceutical Sciences, Professor of the Department of Inorganic and Physical Chemistry, National University of Pharmacy of the Ministry of Health of Ukraine. E-mail: vikpharm@gmail.com. ORCID: http:// orcid.org/0000-0001-8620-2225 Lozova O., PhD in Pharmacy, Associate Professor of the Department of Pharmaceutical and Biological Chemistry, Pharmacognosy, Private Higher Educational Institution “Kyiv Medical University”. E-mail: Lozovaolena2012@gmail.com Відомості про авторів:

Маміна О. О., докторка фармац. наук, професорка кафедри неорганічної та фізичної хімії, Національний фармацевтичний університет Міністерства охорони здоров'я України. E-mail: a_mamina@ukr.net. ORCID: http://orcid.org/0000-0001-6673-1488

Кабачний В. І., доктор фармац. наук, професор кафедри неорганічної та фізичної хімії, Національний фармацевтичний університет Міністерства охорони здоров'я України. E-mail: vikpharm@gmail.com. ORCID: http:// orcid.org/0000-0001-8620-2225

Лозова О. В., кандидатка фармац. наук, доцентка кафедри фармацевтичної та біологічної хімії, фармакогнозії, Приватний вищий навчальний заклад «Київський медичний університет». E-mail: Lozovaolena2012@gmail.com Сведения об авторах:

Мамина Е. А., доктор фармац. наук, профессор кафедры неорганической и физической химии, Национальный фармацевтический университет Министерства здравоохранения Украины. E-mail: a_mamina@ukr.net. ORCID: http://orcid.org/0000-0001-6673-1488 Кабачный В. И., доктор фармац. наук, профессор кафедры неорганической и физической химии, Национальный фармацевтический университет Министерства здравоохранения Украины. E-mail: vikpharm@gmail.com. ORCID: http:// orcid.org/0000-0001-8620-2225 Лозовая Е. В., кандидат фармац. наук, доцент кафедры фармацевтической и биологической химии, фармакогнозии, Частное высшее учебное заведение «Киевский медицинский университет». E-mail: Lozovaolena2012@ gmail.com

Надійшла до редакції 05.08.2020 p. 